\title{
Characterization of recombinant laccase from Trametes versicolor synthesized by Arxula adeninivorans and its application in the degradation of pharmaceuticals
}

\author{
Katarzyna Litwińska ${ }^{1}$, Felix Bischoff ${ }^{1,2}$, Falko Matthes ${ }^{1}$, Rüdiger Bode ${ }^{3}$, Twan Rutten ${ }^{1}$ and Gotthard Kunze ${ }^{1^{*}}$ (D)
}

\begin{abstract}
Recent years have seen an increasing interest in laccase enzymes. Due to their ability of oxidizing various substrates, they are nowadays applied in multiple industrial fields including pulp delignification, textile dye bleaching, and bioremediation. In contrast to laccase production from native sources, with its generally low yield and high cost, heterologous laccase expression is far better suited to meet the growing industrial demands. TVLCC5 gene encoding Trametes versicolor laccase 5 was overexpressed in Arxula adeninivorans using the strong constitutive TEF1 promoter. Recombinant Tvlcc5 protein was purified by immobilized-metal ion affinity chromatography and biochemically characterized using 2,2'-azino-bis(3-ethylbenzothiazoline-6-sulphonic acid) (ABTS) as substrate for standard activity assays. The enzyme showed the highest activity at $50^{\circ} \mathrm{C}$ between $\mathrm{pH} 4.5-5.5$. The half-life of Tvlcc5 at $60^{\circ} \mathrm{C}$ was around $20 \mathrm{~min}$. The negative effect of chloride anions on enzyme activity was demonstrated. A fed-batch cultivation of Tvlcc5 producing strain A. adeninivorans G1212/YRC102-TEF1-TVLCC5-6H was performed and resulted in a laccase activity of $4986.3 \mathrm{UL}^{-1}$. To improve the expression level of recombinant laccase in A. adeninivorans, cultivation conditions were optimized by single factor experiments. Recombinant Tvlcc5 proved to be a promising agent for degradation of pharmaceuticals that are an important source of environmental pollution. Concentration of diclofenac and sulfamethoxazole decreased to $46.8 \%$ and $51.1 \%$ respectively after $24 \mathrm{~h}$ incubation with Tvlcc5. When $1 \mathrm{mM}$ redox mediator ABTS was added complete degradation was obtained within $1 \mathrm{~h}$.
\end{abstract}

Keywords: Arxula adeninivorans, Laccase, Degradation, Pharmaceuticals, Yeast

\section{Introduction}

Annual worldwide intake of active pharmaceutical ingredients (APIs) is estimated at 100,000 tons (Touraud and Roig 2008). Consumption varies strongly between countries but is particularly high in Europe with values between 50 and 150 g per year and capita.

Lipid regulators, antibiotics, antiepileptic and antiinflammatory drugs as well as $\beta$-blockers and antidepressants are amongst the most commonly prescribed pharmaceuticals (Huschek et al. 2004; Fent et al. 2006).

\footnotetext{
*Correspondence: kunzeg@ipk-gatersleben.de

${ }^{1}$ Leibniz Institute of Plant Genetics and Crop Plant Research (IPK),

Corrensstr. 3, 06466 Gatersleben, Germany

Full list of author information is available at the end of the article
}

Due to the low absorption capacity of most APIs, they leave the human body unaffected or as a metabolite over the renal system, thus ending up in the world's water system. This problem is intensified through improper disposal of unused or expired medicinal products. It is estimated that approximately $50 \%$ of patients in USA and UK store those products in their households and more than half discard them in household waste or flush them down the toilet or sink (Bound and Voulvoulis 2005; Seehusen and Edwards 2006). In EU 50\% or more of unused pharmaceuticals is also not returned to the pharmacy (European Environment Agency 2010; BIO Intelligence Service 2013). The amount of unused medicinal products in Germany is assessed to 5700 tons/year. The START 
survey, published in 2008, showed that nearly half of the German citizens dispose unused liquid medicinal products in drains or toilets, and $15.7 \%$ at least occasionally dispose unused or expired tablets in the toilet (Keil 2008). This behavior has led to increasing concentrations of certain APIs in wastewater treatment plants. Natural processes including biological degradation, sorption, air stripping, or phototransformation can remove only part of the APIs and their effectiveness is highly dependent on the environmental conditions of each wastewater treatment plant (Andreozzi et al. 2003; Carballa et al. 2004; Joss et al. 2006).

Processes like ozonation and UV-treatment that have been developed to enhance the degradation processes are under suspicion of causing products with an even higher negative impact on the ecosystem (Okuda et al. 2008; BIO Intelligence Service 2013).

The higher reaction specificity of an enzymatic approach could tackle this problem. In order to eliminate negative effects of pharmaceutically active compounds on the ecological system, one must prevent the binding to their specific receptors. In the present study, laccase was used to achieve this goal. Laccases are multicopper oxidases capable of interacting with a wide spectrum of phenolic compounds, in most cases leading to the formation of radicals. Under low oxygen conditions oxidative polymerization prevails, leading to the formation of polyphenols, which are not recognized anymore by the receptors (Gianfreda et al. 1999; Giardina et al. 2010).

APIs that are not phenolic, but contain benzene-like ring structures, can be transformed into phenolics by cytochrome P450 (CYP450). Expressed in cells of the human liver, CYP450 are naturally involved in the processing of pharmaceuticals in the human body. They increase the solubility of API by hydroxylation, which enables the excretion via the renal system (Wrighton and Stevens 1992; Furge and Guengerich 2006). These hydroxylated pharmaceuticals might be recognized as substrates by the laccase.

The yeast Arxula (Blastobotrys) adeninivorans contains several different genes encoding for CYP450 and thus can be employed for the removal of pharmaceutically active compounds in wastewater treatment plants. However, laccase genes are absent from the genome of this yeast. In this study laccase genes from the fungi Trametes versicolor and Pycnoporus cinnabarinus were expressed in the yeast $A$. adeninivorans with the future aim of generating a whole cell biocatalyst containing the activities of both laccase, attached to the cell surface and CYP450, which are essential for the inactivation of pharmaceutically active compounds from wastewater by oxidative polymerization.

\section{Materials and methods}

\section{Strains and cultivation conditions}

Escherichia coli strain XL1-Blue MRF' $\Delta(m c r A) 183$ $\Delta$ (mcrCB-hsdSMR-mrr)173 endA1 supE44 thi-1 recA1 gyrA96 relA1 lac $\left[\mathrm{F}^{\prime}\right.$ proAB lacI ${ }^{q} Z \Delta M 15$ Tn10 $\left(\right.$ Tet $\left.\left.^{\mathrm{r}}\right)\right]$, obtained from Invitrogen (Carlsbad, USA), was used for cloning procedures. E. coli was grown at $37{ }^{\circ} \mathrm{C}$ in lysogeny broth (LB) medium supplemented with kanamycin for selection. The auxotrophic mutant $A$. adeninivorans G1212 (aleu2 atrp1::ALEU2), derived from A. adeninivorans LS3 which is deposited as $A$. adeninivorans SBUG 724 in the strain collection of the Department of Biology of the University of Greifswald, was used as the recipient strain (Kunze and Kunze 1994; Steinborn et al. 2007). $A$. adeninivorans was grown at $30{ }^{\circ} \mathrm{C}$ under nonselective conditions in complex (YDP) medium or under selective conditions in yeast minimal medium (YMM) supplemented with $2 \%(\mathrm{w} / \mathrm{v})$ glucose as carbon source (Tanaka et al. 1967; Rose et al. 1990).

Fungi $T$. versicolor and $P$. cinnabarinus, which were obtained from the strain collection of the Department of Biology of the University of Greifswald and are listed there as SBUG-M1050 and SBUG-M1044 respectively, were grown on straw (inducing conditions for laccase production) at $30{ }^{\circ} \mathrm{C}$ (Herter et al. 2011).

\section{Isolation and heterologous expression of laccase genes}

After 17 days mycelia of $T$. versicolor and $P$. cinnabarinus were harvested and total RNA was extracted using RNeasy Plus Mini Kit (Qiagen, Hilden, Germany). The cDNA was synthesized by reverse transcriptase (RevertAid Reverse Transcriptase, Thermo Fisher Scientific, Dreieich, Germany). Primers were designed based on the gene sequences taken from NCBI GenBank database (Ong et al. 1997; Otterbein et al. 2000; Benson 2004). Laccase genes with native secretion signals (GenBank Accession numbers: U44430.2, AF170093.1, U44851.1, U44431.1) were amplified by PCR using primers shown in Additional file 1: Table S1. Amplified fragments were inserted into Xplor3.2 plasmid (Bischoff et al. 2017) linearized with PacI restriction enzyme, using Gibson Assembly Master Mix [New England Biolabs (NEB), Frankfurt am Main, Germany], resulting in recombinant plasmids, which were verified by DNA sequencing. Linearization with AscI led to fragments flanked with 25S rDNA sequences (yeast rDNA integrative cassettes-YRCs) for homologous and with SbfI (yeast integrative cassettesYICs) for non-homologous recombination. Linearized fragments were used for transformation of competent $A$. adeninivorans G1212.

To verify presence of laccase genes, genomic DNA of created strains was isolated and used as template for PCR 
reactions with corresponding primers listed in Additional file 1: Table S1.

Laccase gene expressing strains were preselected using 2,2'-azino-bis(3-ethylbenzothiazoline-6-sulphonic acid) (ABTS) and guaiacol agar plates. YMM plates were supplemented with $0.5 \mathrm{mM} \mathrm{CuSO}_{4}$ and $0.2 \mathrm{mM} \mathrm{ABTS}$ or 0.01\% guaiacol (Soden et al. 2002; Kiiskinen et al. 2004). Appearance of green (ABTS) or red (guaiacol) halo was proof of positive transformants, which were selected and cultivated in 48-deep well plates containing YMM supplemented with $0.4 \mathrm{mM} \mathrm{CuSO}_{4}$ at $30{ }^{\circ} \mathrm{C}$ and $180 \mathrm{rpm}$. Supernatant was collected and screened for laccase activity with ABTS as substrate. Best transformant was selected for further analysis.

\section{Analysis of laccase gene expression}

The strains A. adeninivorans G1212/YRC102-TEF1-TVLCC5 -6H, A. adeninivorans G1212/YRC102-TEF1-TVLCC2-6H, A. adeninivorans G1212/YRC102-TEF1-TVLAC-6H, and A. adeninivorans G1212/YRC102-TEF1-PCLAC-6H were pre-cultivated in $10 \mathrm{~mL} \mathrm{YMM-NO}$ with $2 \%$ glucose for $24 \mathrm{~h}$ and subsequently transferred to a second pre-culture of $50 \mathrm{~mL} \mathrm{YMM-NO} \mathrm{N}_{3}$ with $2 \%$ glucose and $0.4 \mathrm{mMCuSO}_{4}$. After $48 \mathrm{~h}$, each strain was transferred to a $200 \mathrm{~mL}$ main culture of the same medium. The transfer was performed by centrifugation $(4000 \times g)$ of the whole pre-culture and resuspension in the fresh medium. All cultivations were carried out at $30^{\circ} \mathrm{C}$ and with an initial $\mathrm{pH}$ 5.8. Sampling occurred at 0, 2, 6, 24, $30,48,72,96$, and $120 \mathrm{~h}$. Two pellets of each sample were obtained by centrifugation and washing with deionized water. Supernatant was collected and stored on ice for further analysis. One pellet was used for RNA extraction using RNeasy Plus Mini Kit (Qiagen, Hilden, Germany). Proteins were extracted from the second pellet using Mixer Mill MM 400 (Retsch, Haan, Germany) and Mcllvaine buffer (pH 3.0). The RNA was used for cDNA synthesis with reverse transcriptase (RevertAid Reverse Transcriptase, Thermo Fisher Scientific, Dreieich, Germany). PCR using gene specific primers (Additional file 1: Table S1) was performed on cDNA to confirm transcription of each laccase gene. AAHEXK and AATFIID were used as positive control to show integrity of the cDNA.

\section{Enzyme activity assay}

The laccase activity was determined for the oxidation of ABTS. The reaction mixture $(100 \mu \mathrm{L})$ contained $50 \mathrm{mM}$ McIlvaine buffer ( $\mathrm{pH} 3.0$ ), $3.5 \mathrm{mM}$ ABTS, and $10 \mu \mathrm{L}$ of suitably diluted sample. The appearance of green color due to ABTS oxidation was measured spectrophotometrically at $420 \mathrm{~nm}\left(\varepsilon=36,000 \mathrm{M}^{-1} \mathrm{~cm}^{-1}\right)$ in a Tecan Infinite M200 Microplate Reader (Tecan, Männedorf, Switzerland). In experiments where activity for 2,6-dimethoxyphenol (2,6-DMP) and syringaldazine
(SGZ) was also determined, concentration of substrate in the reaction mixture was 3.5 and $0.13 \mathrm{mM}$ respectively. Measurements were performed at $477 \mathrm{~nm}$ $\left(\varepsilon=14,800 \mathrm{M}^{-1} \mathrm{~cm}^{-1}\right)$ for 2,6-DMP and at $530 \mathrm{~nm}$ $\left(\varepsilon=65,000 \mathrm{M}^{-1} \mathrm{~cm}^{-1}\right)$ for syringaldazine. All experiments were carried out in triplicate. One unit is defined as the amount of enzyme that oxidizes $1 \mu \mathrm{mol}$ of substrate per min under assay conditions.

\section{Effect of $\mathrm{pH}$ and temperature on activity and stability of laccase}

To estimate optimal $\mathrm{pH}$, laccase activity of purified protein was measured in the presence of $50 \mathrm{mM}$ McIlvaine buffers with $\mathrm{pH}$ range 2.2-8.0. Ionic strength of buffers was adjusted to $500 \mathrm{mM}$ by addition of $\mathrm{NaNO}_{3}$. The $\mathrm{pH}$ optimum was estimated for three substrates: ABTS, 2,6DMP, and syringaldazine.

The same buffers were used for $\mathrm{pH}$ stability test. Enzyme was incubated at certain $\mathrm{pH}$ on ice and residual activity was measured after $10 \mathrm{~min}, 2$ and $24 \mathrm{~h}$ with ABTS as substrate.

Optimal temperature was estimated by incubation of the enzyme on ice and in PCR thermocycler at temperatures ranging from 20 to $70{ }^{\circ} \mathrm{C}$. Mixture of Mcllvaine buffer ( $\mathrm{pH}$ 3.0) and ABTS was preincubated at certain temperature for 5 min before enzyme was added. Reaction was stopped after 5 min by adding $0.625 \mathrm{M}$ oxalic acid. Relative activity was measured spectrophotometrically as described above.

The effect of temperature on enzyme stability was tested by incubating the enzyme on ice and in PCR thermocycler (temperature ranging from 20 to $80{ }^{\circ} \mathrm{C}$ ) and measuring residual activity after $10,30,60,90$, and 120 min by standard assay.

\section{Effect of ionic strength on laccase activity}

Influence of ionic strength was estimated in presence of $\mathrm{NaNO}_{3}$ and $\mathrm{NaCl}$. Reactions with ionic strength ranging from 0.25 to $2 \mathrm{M}$ were performed and laccase activity was measured. Enzyme activity of samples with the lowest ionic strength $(0.25 \mathrm{M})$ was defined as $100 \%$ and used for calculation of relative activity values.

\section{Determination of kinetic constants}

$K_{\mathrm{M}}$ and $k_{\text {cat }}$ values of purified enzyme were determined for ABTS and 2,6-DMP as substrates. Concentration of each substrate was in the range $0.5-10 \mathrm{mM}$. Enzymatic activities were measured in $50 \mathrm{mM}$ citrate-phosphate buffer $\mathrm{pH} 5.0$ and $25{ }^{\circ} \mathrm{C}$. Kinetic constants of Michaelis-Menten plot were calculated using non-linear regression. 


\section{Influence of metal ions and cofactors}

The influence of different metal ions and cofactors on enzyme activity was determined by standard activity assay (described above) supplemented with $1 \mathrm{mM}$ final concentration of $\mathrm{AlCl}_{3}, \mathrm{CaCl}_{2}, \mathrm{CaSO}_{4}, \mathrm{CoCl}_{2}, \mathrm{CuCl}_{2}$, $\mathrm{CuSO}_{4}, \mathrm{FeCl}_{3}, \mathrm{FeSO}_{4}, \mathrm{KCl}, \mathrm{MgCl}_{2}, \mathrm{MgSO}_{4}, \mathrm{MnCl}_{2}$, $\mathrm{MnSO}_{4}, \mathrm{NiCl}_{2}, \mathrm{NiSO}_{4}, \mathrm{ZnCl}_{2}, \mathrm{ZnSO}_{4}$, or EDTA and subsequent measurement of remaining enzymatic activity. Activity assay without supplementation served as control.

\section{Optimization of laccase production}

To investigate the influence of copper ions on laccase activity, culture medium was supplemented with $\mathrm{CuSO}_{4}$ in concentrations within the range of $0.2-2 \mathrm{mM}$.

To examine the influence of cultivation temperature on laccase production five Erlenmeyer flasks with $\mathrm{YMM}+\mathrm{NO}_{3}$ supplemented with $0.2 \mathrm{mM} \mathrm{CuSO}_{4}$ were equally inoculated with $A$. adeninivorans $\mathrm{G1212} /$ YRC102-TEF1-TVLCC5-6H. Each flask was incubated at a different temperature $\left(10,20,30,37,42{ }^{\circ} \mathrm{C}\right)$ for the whole experimental procedure. Yield coefficients $Y_{X / S}$ for dry cell weight and $Y_{P / S}$ for enzymatic activity were calculated using maximal values for biomass and activity as follows:

$$
\begin{aligned}
& Y_{X_{/ S}}=\frac{D C W_{t}-D C W_{0}}{G l c_{0}-G l c_{t}} \\
& Y_{P_{/ S}}=\frac{A c t_{t}-A c t_{0}}{G l c_{0}-G l c_{t}}
\end{aligned}
$$

\section{Purification of Tvlcc5}

Supernatant of a culture of A. adeninivorans G1212/ YRC102-TEF1-TVLCC5-6H was harvested after 7 days of growth in $\mathrm{YMM}$ at $30{ }^{\circ} \mathrm{C}$ by centrifugation $(4000 \times g$, $5 \mathrm{~min}$ ) and subsequently incubated with an equal volume of binding buffer $(500 \mathrm{mM} \mathrm{NaCl}, 5 \mathrm{mM}$ imidazole, $20 \mathrm{mM}$ Tris $-\mathrm{HCl} \mathrm{pH}$ 7.9). The mixture was loaded onto a Ni-NTA column and washed with one volume of binding buffer. After a second washing step with washing buffer containing $500 \mathrm{mM} \mathrm{NaCl}, 30 \mathrm{mM}$ imidazole, and $20 \mathrm{mM}$ Tris- $\mathrm{HCl} \mathrm{pH}$ 7.9, protein was eluted with elution buffer containing $1 \mathrm{M}$ imidazole. Removal of imidazole from elution fractions was performed using PD10 columns (GE Healthcare, Freiburg, Germany) and PBS buffer (phosphate-buffered saline). Purified protein was stored on ice in PBS buffer, pH 7.4 for further analysis.

\section{SDS-PAGE and molecular mass determination}

Sodium dodecyl sulfate polyacrylamide gel electrophoresis with $10 \%$ separation gel and $4 \%$ stacking gel was carried out like described by Laemmli (1970). PageRuler
Prestained Protein Ladder (Thermo Fisher Scientific, Dreieich, Germany) was used as a molecular mass marker. Protein bands were stained with InstantBlue solution (Expedeon, San Diego, USA). Western blotting was carried out by electrotransfer onto a polyvinylidene difluoride membrane. Laccase was detected using a primary polyclonal rabbit anti- $6 \times$ His-tagged antibody, $200 \mathrm{ng} \mathrm{mL} \mathrm{m}^{-1}$ (MicroMol, Karlsruhe, Germany) in combination with an alkaline phosphatase-conjugated goat

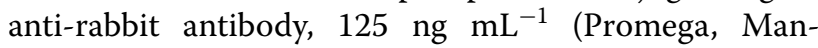
nheim, Germany). Substrate for alkaline phosphatase was nitroblue tetrazolium-5-bromo-4-chloro-3-indolylphosphate (NBT-BCIP) (Roche, Mannheim, Germany).

Native molecular mass was determined by size exclusion chromatography using a Superdex 200 column (1 by $50 \mathrm{~cm}$ ) and $20 \mathrm{mM}$ Tris- $\mathrm{HCl}$ buffer $(\mathrm{pH} \mathrm{7.0)}$ with $150 \mathrm{mM} \mathrm{NaCl}$ at a flow rate of $1 \mathrm{~mL} \mathrm{~min}{ }^{-1}$. A mixture of ferritin $(450 \mathrm{kDa})$, catalase $(240 \mathrm{kDa})$, bovine serum albu$\min (67 \mathrm{kDa})$, and RNase A (13.7 kDa) served as molecular mass standard.

\section{Glycoprotein and activity staining}

Glycoprotein staining was performed after SDS-PAGE development. Gels were washed $3 \times 30 \mathrm{~min}$ in ethanol, acetic acid, water (3:1:6) solution followed by $1 \mathrm{~h}$ incubation in oxidizing solution (1\% sodium metaperiodate in $7.5 \%$ acetic acid) in the darkness. After $5 \times 30 \mathrm{~min}$ washing with $7.5 \%$ acetic acid, staining was carried out in fuchsin-sulfite solution (1\% basic fuchsin, $1.9 \%$ sodium metabisulfite in $0.15 \mathrm{M} \mathrm{HCl}$ ) for $1 \mathrm{~h}$ in the dark. Stained gels were washed in $1 \%$ sodium metabisulfite solution in $0.1 \mathrm{M} \mathrm{HCl} 5 \times 30 \mathrm{~min}$ and afterwards $30 \mathrm{~min}$ in water.

Activity staining was performed using native PAGE. Enzyme bands were visualized by incubating the gel in $50 \mathrm{mM}$ sodium acetate buffer $\mathrm{pH} 4.5$ containing $0.5 \mathrm{mM}$ ABTS or 2,6-DMP.

\section{Deglycosylation of Tvlcc5}

$N$-linked glycans were removed from purified protein by treatment with PNGase F according to the manufacturer's protocol (NEB, Frankfurt am Main, Germany). The product of endoglycosidase treatment was analyzed by SDS-PAGE and western blotting.

\section{Fed-batch fermentation}

Fed-batch cultivation was carried out in a 5 L BIOSTAT Bplus TWIN (Sartorius, Göttingen, Germany) with a starting volume of $3 \mathrm{~L}$ medium containing $0.2 \mathrm{M}$ glucose, $40 \mathrm{~g} \mathrm{~L}^{-1}$ peptone, $20 \mathrm{~g} \mathrm{~L}^{-1}$ yeast extract, $86.9 \mathrm{mM}$ $\mathrm{NH}_{4} \mathrm{H}_{2} \mathrm{PO}_{4}, 20.1 \mathrm{mM} \quad \mathrm{K}_{2} \mathrm{HPO}_{4}, 25.7 \mathrm{mM} \mathrm{KH}_{2} \mathrm{PO}_{4}$, $8.1 \mathrm{mM} \mathrm{MgSO}{ }_{4} \cdot 7 \mathrm{H}_{2} \mathrm{O}, 0.1 \%(\mathrm{v} / \mathrm{v})$ trace elements solution, $84.7 \mu \mathrm{M} \mathrm{Ca}\left(\mathrm{NO}_{3}\right)_{2} \cdot 4 \mathrm{H}_{2} \mathrm{O}$, and $7.4 \mu \mathrm{M} \mathrm{FeCl} \cdot 6 \mathrm{H}_{2} \mathrm{O}$. The medium was supplemented with $0.4 \mathrm{mM} \mathrm{CuSO}_{4}$. 
Feeding was growth controlled using a custom made S88 protocol (BioPAT ${ }^{\circledR} \mathrm{MFCS} /$ win 3.0, Sartorius, Göttingen, Germany). Stirrer speed was used as indirect indicator for growth via oxygen uptake. Feeding was initiated when stirrer speed dropped below $800 \mathrm{rpm}$ each feeding cycle. Salt feed medium contained $1.4 \mathrm{mM} \mathrm{NH}_{4} \mathrm{H}_{2} \mathrm{PO}_{4}, 0.2 \mathrm{mM}$ $\mathrm{MgSO}_{4} \cdot 7 \mathrm{H}_{2} \mathrm{O}, 6 \%(\mathrm{v} / \mathrm{v})$ trace elements solution, $5.1 \mathrm{mM}$ $\mathrm{Ca}\left(\mathrm{NO}_{3}\right)_{2} \cdot 4 \mathrm{H}_{2} \mathrm{O}$, and $0.4 \mathrm{mM} \mathrm{FeCl} \cdot 6 \mathrm{H}_{2} \mathrm{O}$. Sugar feed medium contained $50 \%(\mathrm{w} / \mathrm{v})$ glucose. Feeding stocks were supplemented with $0.4 \mathrm{mM} \mathrm{CuSO}_{4}$. The C:N-ratio was kept constant during the whole feeding procedure. Fermentation was carried out at $30{ }^{\circ} \mathrm{C}, \mathrm{pH}$ was maintained at 6.0 using $10 \% \mathrm{NaOH}$ and $10 \% \mathrm{H}_{2} \mathrm{SO}_{4}$. To prevent foam formation, Struktol SB 2071 (Schill + Seilacher, Böblingen, Germany) was used as antifoam agent.

\section{Degradation of pharmaceuticals}

Degradation reactions were performed in Erlenmeyer flasks containing lyophilized Tvlcc5 $\left(20 \mathrm{U} \mathrm{mL}^{-1}\right), 50 \mathrm{mM}$ sodium citrate buffer $\mathrm{pH}$ 5.0, and $40 \mathrm{mg} \mathrm{L}^{-1}$ tested pharmaceutical (carbamazepine, diclofenac sodium salt, sulfamethoxazole). Flasks were incubated at $30{ }^{\circ} \mathrm{C}$ on a shaker $(180 \mathrm{rpm})$ for $24 \mathrm{~h}$. Samples were taken after $30 \mathrm{~min}, 1,2,4,8$, and $24 \mathrm{~h}$. Influence of laccase redox mediator on degradation process was tested by addition of $1 \mathrm{mM}$ ABTS to the reaction mixture. Samples were analyzed by thin-layer chromatography.

\section{Thin-layer chromatography (TLC)}

Prior to TLC analysis samples were extracted with 1 vol. ethyl acetate. CAMAG Automatic TLC Sampler (CAMAG, Muttenz, Switzerland) was used for sample application on pre-coated TLC sheets POLYGRAM SIL G/UV ${ }_{254}$ (Macherey-Nagel, Düren, Germany). Plates were developed with hexane, ethyl acetate, and acetic acid (60:40:0.1) as eluent and were analyzed with a CAMAG TLC Scanner. $\mathrm{R}_{\mathrm{f}}$ values and amounts of each compound were calculated using winCATS software (CAMAG, Muttenz, Switzerland).

\section{Results}

\section{Screening for laccase activity}

For the isolation of laccase genes, the fungi $T$. versicolor and $P$. cinnabarinus were grown in YPD medium containing straw and $\mathrm{CuSO}_{4}$ to induce laccase gene expression. Mycelia were harvested after 17 days of cultivation and subsequently used for RNA extraction. Four ORF's encoding for laccases were amplified via PCR (see "Materials and methods"). After construction of expression cassettes containing the strong constitutive TEF1 promoter from $A$. adeninivorans and the $S$. cerevisiae derived $P H O 5$ terminator, the yeast strain $A$. adeninivorans $\mathrm{G} 1212$ was transformed and screened for laccase secretion using solid media with ABTS or guaiacol as substrate. Both types of transformants were screened (with homologous and non-homologous integration) and obtained results were comparable. The strains showing the strongest green or red halo were chosen for further quantification of laccase activity in liquid minimal medium (YMM) containing $0.5 \mathrm{mM} \mathrm{CuSO}_{4}$. Presence of all four laccase genes in respective strains of $A$. adeninivorans $\mathrm{G} 1212$ was confirmed by PCR on isolated genomic DNA using primers for laccase genes amplification (Additional file 1: Fig. S1). However, only strains containing the TVLCC5 gene showed secretion of active laccase into the culture medium (Fig. 1). The best transformant of $A$. adeninivorans G1212/YRC102-TEF1-TVLCC5-6H was taken for further analysis.

To exclude potential dysfunctionality of the secretion system, intracellular laccase activity was measured and western blot analysis using anti- $6 \times$ His antibody was performed for all four strains (Additional file 1: Fig. S2, section I and II). Obtained results indicate lack of synthesis of Tvlac, Tvlcc2, and Pclac. Within analyzed time point samples no degradation products of those proteins were identified.

For strain A. adeninivorans G1212/YRC102-TEF1TVLCC5-6H distribution of active enzyme between intra- and extracellular fractions during cultivation process was analyzed (Additional file 1: Fig. S2, section III). Amount of secreted protein is increasing during cell growth, reaching the maximum of $89.4 \pm 0.4 \%$ after $120 \mathrm{~h}$.

Reverse transcription PCR was performed to analyse expression of TVLAC, TVLCC2, and PCLAC. Therefore, RNA was extracted from samples taken over the cultivation time of the described experiment (Analysis of laccase gene expression, "Materials and methods"). After cDNA synthesis, PCR was performed using primers amplifying 150 to $220 \mathrm{bp}$ large fragments of a non-conserved region of each gene to eliminate false positive bands amplified from multi-copper oxidase like genes from $A$. adeninivorans. The genes for hexokinase (AAHEXK) and transcription initiation factor AATFIID were used as positive control to verify the integrity of the extracted RNA as well as to normalise the signal intensity to some extent. Additional file 1: Fig. S3a shows the amplified PCR fragments after $24 \mathrm{~h}$ of cultivation. Positive results were obtained for both control genes as well as TVLCC5, $T V L C C 2$, and PCLAC. On the other hand, no amplification was achieved for TVLAC after $24 \mathrm{~h}$. Additionally, it is shown that a positive signal was only obtained from the respective primers for each laccase gene, which means there is no cross signal and only one laccase gene is present in each strain. TVLCC2 and TVLAC being an obvious exception since they show sequence similarity so that 


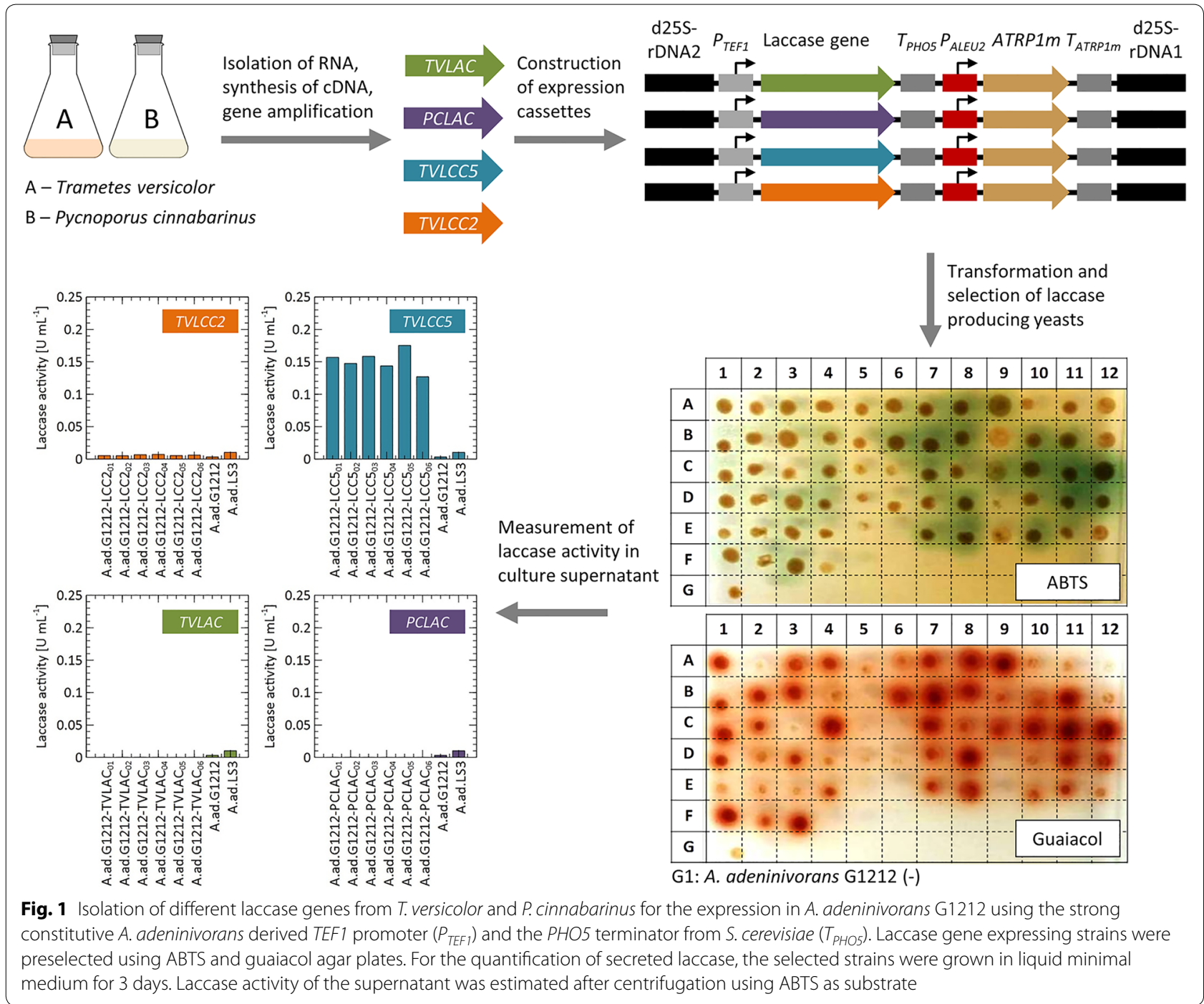

the same primers were used for amplification. Since no signal was detected from $T V L A C$, to verify expression a time course experiment was performed to examine for earlier or later expression than $24 \mathrm{~h}$ of cultivation time. Additional file 1: Fig. S3b shows that a positive signal was only detected in cDNA from samples taken after $2 \mathrm{~h}$ of cultivation. All other time points were negative for expression of TVLAC. We found a positive signal also for $P C L A C$ after $2 \mathrm{~h}$ of cultivation, but not for $T V L C C 2$ and TVLCC5 (Additional file 1: Fig. S3c).

\section{Expression and purification of Tvlcc5}

For purification and further analysis of Tvlcc5, it was necessary to assess the maximum activity during the cultivation. Therefore, three different media differing in the $\mathrm{N}$-source were used and analyzed, concerning growth behavior and laccase secretion. Four different $\mathrm{CuSO}_{4}$ concentrations ranging between
0.2 and $2.0 \mathrm{mM}$ were used to find the optimum for the synthesis of Tvlcc5. The results, summarized in Fig. 2 and Table 1, show that the best growth condition were found in the complex YPD medium with peptone and yeast extract as nitrogen source resulting in a yield of $0.68 \pm 0.03 \mathrm{~g}_{\mathrm{DCW}} \mathrm{g}_{\text {glc }}^{-1}$. The minimal media with $\left(\mathrm{NH}_{4}\right)_{2} \mathrm{SO}_{4}$ or $\mathrm{NaNO}_{3}$ as nitrogen source gave comparable yields of $0.44 \pm 0.04 \mathrm{~g}_{\mathrm{DCW}} \mathrm{g}_{\text {glc }}^{-1}$ and $0.41 \pm 0.07 \mathrm{~g}_{\mathrm{DCW}} \mathrm{g}_{\mathrm{glc}}^{-1}$, respectively. Variation in the $\mathrm{pH}$ value during culturing appeared to be depending on the medium used. In YPD medium the $\mathrm{pH}$ initially decreased from $\mathrm{pH} 6.0$ to $\mathrm{pH} 4.5$ after $24 \mathrm{~h}$ before steadily increasing until pH 9.0 after $200 \mathrm{~h}$ of cultivation. The most stable $\mathrm{pH}$ was observed in $\mathrm{YMM}-\mathrm{NO}_{3}$ medium. After a gradual increase to a maximum of $\mathrm{pH}$ 7.0 within the first $60 \mathrm{~h}$ the $\mathrm{pH}$ remained constant for the rest of the cultivation time. The concentration of $\mathrm{CuSO}_{4}$ had a strong effect on both $\mathrm{pH}$ and growth in 

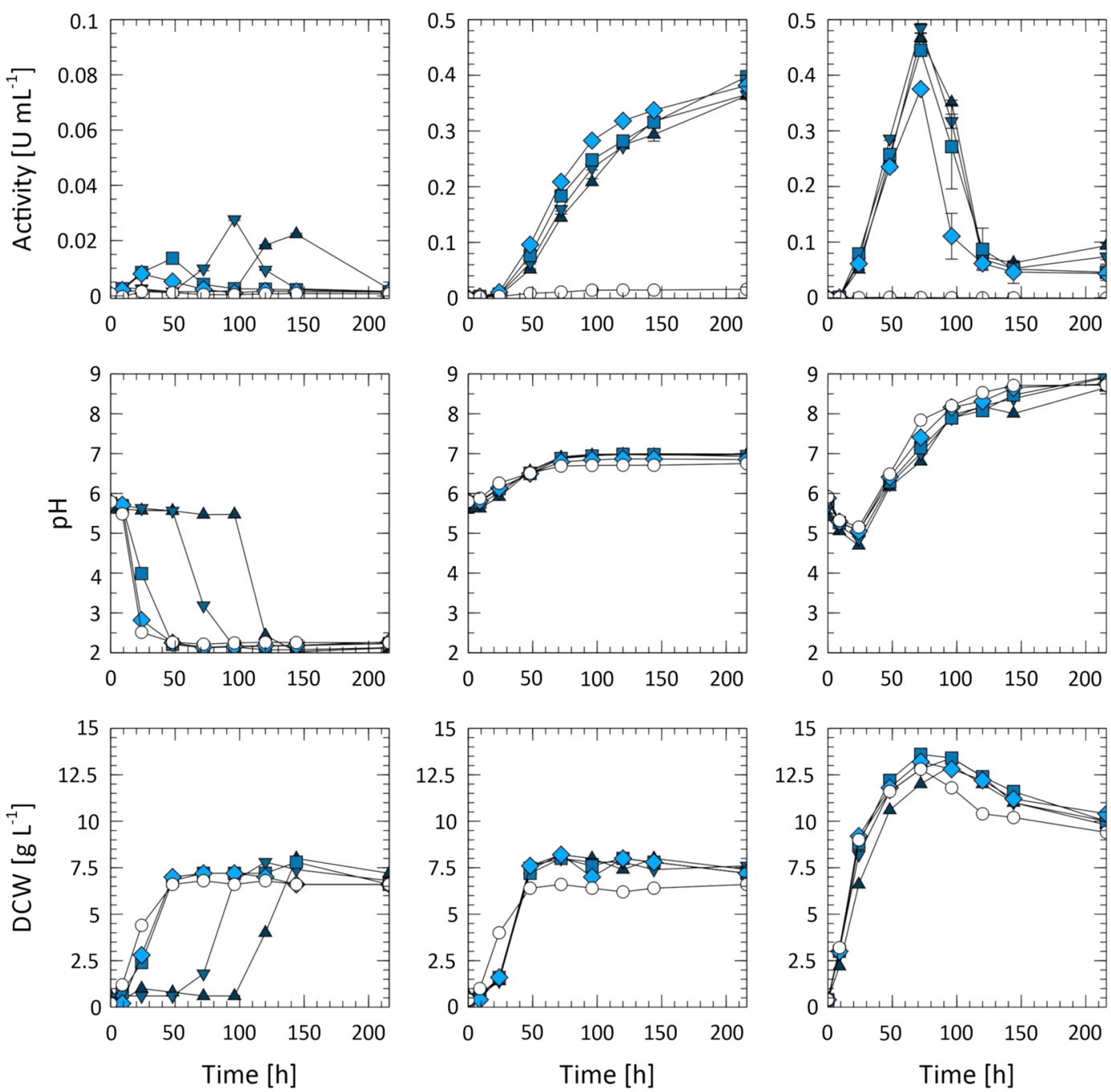

Fig. 2 Analysis of Tvlcc5 synthesis by A. adeninivorans G1212/YRC102-TEF1-TVLCC5-6H in YMM-NH $($ left), YMM-NO 3 (middle), and YPD (right) containing $0 \mathrm{mM}$ (white circle), $0.2 \mathrm{mM}$ (diamond), $0.5 \mathrm{mM}$ (square), $1.0 \mathrm{mM}$ (triangle down), and $2.0 \mathrm{mM}$ (triangle up) $\mathrm{CuSO}_{4}$

Table 1 Summary of the specific yields obtained during the analysis of Tvlcc5 synthesis by A. adeninivorans G1212/ YRC102-TEF1-TVLCC5-6H in YMM- $\mathrm{NH}_{4}\left(\mathrm{NH}_{4}\right), \mathrm{YMM}-\mathrm{NO}_{3}\left(\mathrm{NO}_{3}\right)$ and YPD

\begin{tabular}{|c|c|c|c|c|c|c|c|c|c|}
\hline \multirow[t]{2}{*}{$\mathrm{Cu}^{2+}(\mathrm{mM})$} & \multicolumn{3}{|c|}{$Y_{X / s}\left(g_{D C w} g_{g \mid c}^{-1}\right)$} & \multicolumn{3}{|c|}{$\mathrm{Y}_{\mathrm{P} / \mathrm{S}}\left(\mathrm{mU} \mathrm{g}_{\mathrm{glc}}^{-1}\right)$} & \multicolumn{3}{|c|}{ Max. activity $\left(\mathrm{mU} \mathrm{mL}^{-1}\right)$} \\
\hline & $\mathrm{NH}_{4}$ & $\mathrm{NO}_{3}$ & YPD & $\mathrm{NH}_{4}$ & $\mathrm{NO}_{3}$ & YPD & $\mathrm{NH}_{4}$ & $\mathrm{NO}_{3}$ & YPD \\
\hline 0.00 & 0.45 & 0.33 & 0.66 & 0.07 & 0.82 & 0.08 & 1.55 & 15.86 & 0.85 \\
\hline 0.20 & 0.42 & 0.36 & 0.66 & 1.01 & 20.24 & 25.03 & 7.97 & 381.63 & 375.11 \\
\hline 0.50 & 0.49 & 0.43 & 0.72 & 1.01 & 24.97 & 34.13 & 13.60 & 397.57 & 444.74 \\
\hline 1.00 & 0.45 & 0.49 & 0.64 & 1.86 & 24.78 & 32.64 & 27.65 & 365.48 & 484.70 \\
\hline 2.00 & 0.38 & 0.45 & 0.70 & 1.28 & 23.76 & 35.37 & 22.35 & 363.31 & 467.01 \\
\hline
\end{tabular}

The enzyme yield $\mathrm{Y}_{\mathrm{P} / \mathrm{S}}$ was calculated for the time point on which maximum activity was measured during the cultivation

YMM- $\mathrm{NH}_{4}$ medium. The presence of $\mathrm{NH}_{4}$ caused an acidification of the culture medium, due to extrusion of $\mathrm{H}^{+}$to maintain the necessary gradient for $\mathrm{NH}_{4}$-uptake
(Peña et al. 1987). This caused the $\mathrm{pH}$ drop from $\mathrm{pH} 6.0$ to 2.0 within $48 \mathrm{~h}$ in the presence of $0,0.2$, and $0.5 \mathrm{mM}$ $\mathrm{CuSO}_{4}$, after $100 \mathrm{~h}$ in the presence of $1 \mathrm{mM} \mathrm{CuSO}_{4}$, and 
after $150 \mathrm{~h}$ in the presence of $2 \mathrm{mM} \mathrm{CuSO}_{4}$ (Fig. 2 middle left). A similar time delay was observed for reaching maximum dry cell weight in this medium (Fig. 2 down left). The highest activity of extracellular Tvlcc5 was obtained in YPD medium with an absolute peak after $60 \mathrm{~h}$ of incubation. After this, activity decreased due to laccase degradation in the increasingly alkaline environment. This possibly is a result of utilization of amino acids after depletion of glucose and the subsequent release of ammonia (Vylkova et al. 2011). In $\mathrm{YMM}^{-\mathrm{NO}_{3}}$ an activity of $0.4 \mathrm{U} \mathrm{mL}^{-1}$ was measured after $200 \mathrm{~h}$. Tvcc5 remained stable over the full period of cultivation. In YMM- $\mathrm{NH}_{4}$ only a low accumulation of Tvlcc 5 was detected. In the presence of all $\mathrm{CuSO}_{4}$ concentrations tested, maximum Tvlcc5 activity always concurred with maximum growth rate and medium attaining $\mathrm{pH}$ 2.0. After this peak Tvlcc5 activity decreased to $0.0 \mathrm{U} \mathrm{mL}^{-1}$, implying complete enzyme degradation (Fig. 2 top left). Additionally, no laccase activity was detected in media without the supplementation of $\mathrm{CuSO}_{4}$. Maximum accumulation of laccase was achieved with $0.5 \mathrm{mM} \mathrm{CuSO}_{4}$ in $\mathrm{YMM}^{-\mathrm{NO}_{3}}$ as well as in YPD. Higher concentrations of $\mathrm{Cu}^{2+}$ had no beneficial effect on laccase activity. To verify the influence of cultivation temperature on laccase production, cultures were grown at five different temperatures: 10, 20, 30,37 , and $42{ }^{\circ} \mathrm{C}$ (Fig. 3). Cultures grown at 30, 37, and $42{ }^{\circ} \mathrm{C}$ showed a similar biomass production profile. Cultures grown at $20^{\circ} \mathrm{C}$ showed a longer lag phase but final biomass accumulation was highest. Maximum laccase activity $\left(0.35 \mathrm{U} \mathrm{mL}^{-1}\right)$ was also detected at this temperature with only slightly lower levels of Tvlcc 5 secretion $\left(0.33 \mathrm{U} \mathrm{mL}^{-1}\right)$ measured at $30{ }^{\circ} \mathrm{C}$. Incubation at $10{ }^{\circ} \mathrm{C}$ strongly inhibited growth causing low accumulation of laccase. A similarly low amount of Tvlcc 5 was also detected in the $42{ }^{\circ} \mathrm{C}$ culture, which did show better cell growth compared to the $10{ }^{\circ} \mathrm{C}$ culture.

For the biochemical characterization, it was necessary to purify Tvlcc 5 to homogeneity. Therefore, $4 \mathrm{~L}$ of YMM$\mathrm{NO}_{3}$ were inoculated with $A$. adeninivorans G1212/ YRC102-TEF1-TVLCC5-6H and cultivated for 7 days. The culture supernatant was mixed with one volume of binding buffer leading to a drop in activity from an initial $0.358 \pm 0.013 \mathrm{U} \mathrm{mL}^{-1}$ down to $0.016 \pm 0.004 \mathrm{U} \mathrm{mL}^{-1}$ due to the presence of $\mathrm{Cl}^{-}$ions $(500 \mathrm{mM} \mathrm{NaCl}$, as described in "Materials and methods"). Final activities of $0.882 \pm 0.041,0.589 \pm 0.043$, and $0.326 \pm 0.016 \mathrm{U} \mathrm{mL}^{-1}$ were recovered in three subsequent elution steps. SDSPAGE analysis of the Tvlcc5 elution steps showed a band at around $100 \mathrm{kDa}$ (theoretical molecular mass $53.6 \mathrm{kDa}$ ), which was confirmed by western blotting to be a Histagged protein (Fig. 4a, lane 2). Size exclusion chromatography in native conditions revealed a value of $90 \mathrm{kDa}$, thus corresponding to the result of the SDS-PAGE analysis. Since more than one band was visible after Coomassie staining, a clear native gel was performed to confirm that no other protein with laccase activity was present in the elution fraction. The activity staining with ABTS and 2,6-DMP (Fig. 4b) clearly showed a single band only, indicating sufficient purity for further characterization. The discrepancy between the theoretical molecular mass of $53.6 \mathrm{kDa}$ and the measured value of $100 \mathrm{kDa}$ might be due to hyperglycosylation. Both, staining for glycosylation (Fig. 4a, lane 3) as well as altered SDS-PAGE location after deglycosylation by PNGase F (Fig. 4c) confirmed that Tvlcc5 is highly glycosylated.

\section{Biochemical characterization}

The biochemical parameters of purified Tvlcc5 were analyzed in detail to determine the optimal reaction
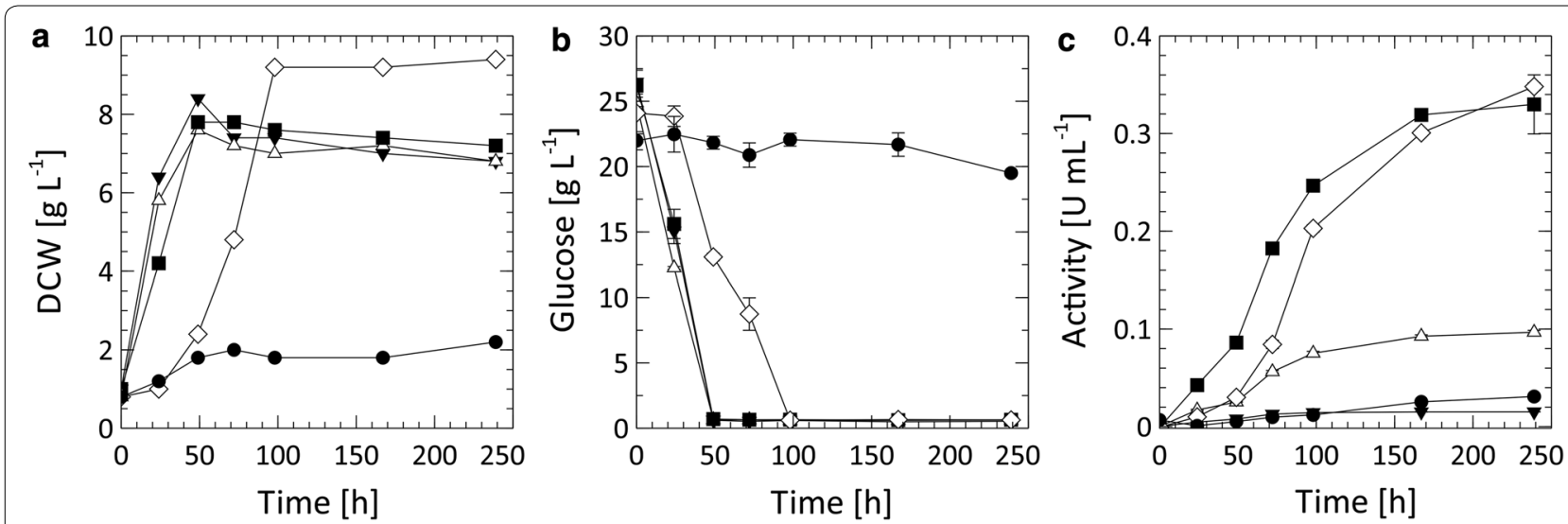

Fig. 3 Effect of cultivation temperature on DCW (a), glucose concentration (b), and laccase activity (c). Strain A. adeninivorans G1212/ YRC102-TEF1-TVLCC5-6H was grown at $10^{\circ} \mathrm{C}$ (black circle), $20^{\circ} \mathrm{C}$ (white diamond), $30{ }^{\circ} \mathrm{C}$ (black square), $37^{\circ} \mathrm{C}$ (white up-pointing triangle), and $42{ }^{\circ} \mathrm{C}$ (black down-pointing triangle) 


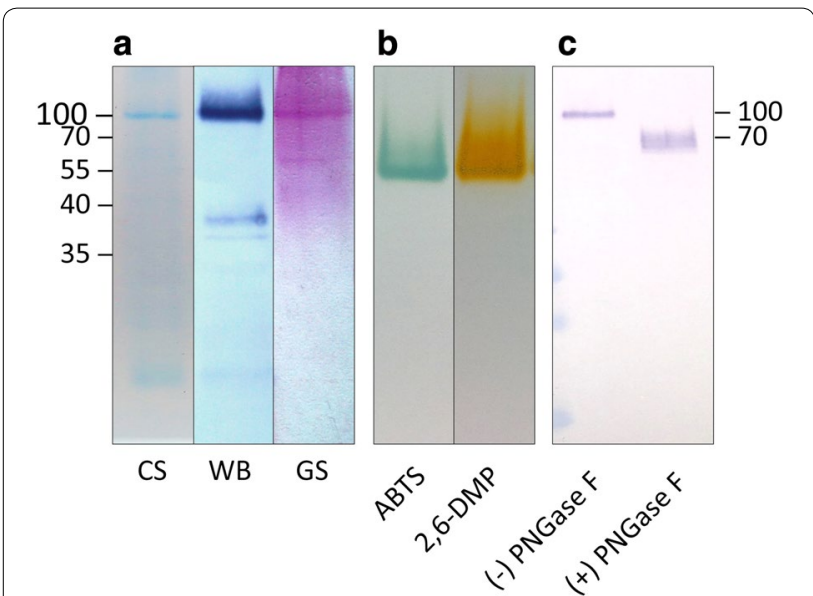

Fig. 4 PAGE analysis of purified Tvlcc5 synthesized in A. adeninivorans G1212/YRC102-TEF1-TVLCC5-6H. a Western-blot signal (WB),

Coomassie (CS) and glycosylation staining (GS) of Tvlcc5 after separation on a $10 \%$ SDS-PAA gel. b Activity staining of Tvlcc5 separated on a clear native gel using ABTS or 2,6-DMP as substrates (no marker was used since separation in native gels is by size and charge simultaneously). c Comparison of the western-blot signals of Tvlcc5 and PNGase F treated Tvlcc5

conditions for its application in the degradation of pharmaceuticals.

The optimal $\mathrm{pH}$ for Tvlcc 5 was between $\mathrm{pH} 4.5$ and 5.0 for the substrates ABTS and 2,6-DMP. In case of SGZ as substrate, the highest relative activity is pH 5.5 (Fig. 5a). The ionic strength of the reaction buffer was found to be a key factor influencing the $\mathrm{pH}$ optimum. Without correction of ionic strength to $0.5 \mathrm{M}$, the $\mathrm{pH}$ optimum for the three substrates used in this experiment varied from $\mathrm{pH} 2.6$ for ABTS, $\mathrm{pH} 3.8$ for 2,6-DMP to $\mathrm{pH} 4.6$ for SGZ (Additional file 1: Fig. S4). Stability of Tvlcc5 was tested by incubation for 2 or $24 \mathrm{~h}$ under various $\mathrm{pH}$ regimes in the presence of buffers with equalized ionic strength. Enzyme instability in acidic conditions measured in loss of initial activity was most extreme at $\mathrm{pH}$ 2.2. Under this condition, activity decreased to $61.0 \pm 6.8 \%$ after $2 \mathrm{~h}$ and was down to $22.7 \pm 7.7 \%$ after $24 \mathrm{~h}$ (data not shown). Substantial drops in activity were also measured at $\mathrm{pH}$ 3.4 after $2 \mathrm{~h}(76.6 \pm 17.7 \%)$ and after $24 \mathrm{~h}(60.1 \pm 12.6 \%)$.

Tvlcc5 activity also depends on the ionic strength of the reaction buffer. Figure $5 \mathrm{~b}$ shows this relationship for $\mathrm{NaNO}_{3}$ and $\mathrm{NaCl}$, which were used to adjust the ionic strength as described in "Materials and methods". Increasing ionic strength to $2 \mathrm{M}$ using $\mathrm{NaNO}_{3}$ led to increase of relative laccase activity to $147.0 \pm 0.7 \%$. On the other hand, using $\mathrm{NaCl}$ led to decrease of activity to $18.2 \pm 2.9 \%$ of initial value.

The relative activity of Tvlcc 5 initially increased with temperatures until $50{ }^{\circ} \mathrm{C}$, before decreasing due to its instability above $55{ }^{\circ} \mathrm{C}$ (Fig. $5 \mathrm{c}$ ). The results show a temperature optimum between 35 and $55{ }^{\circ} \mathrm{C}$ with a maximum activity at $50{ }^{\circ} \mathrm{C}$. Lower activities of 18.4 and $19.8 \%$ were achieved by performing the reaction either on ice or at $70{ }^{\circ} \mathrm{C}$ respectively. The half-life of Tvlcc 5 at $60{ }^{\circ} \mathrm{C}$ was calculated to be $20.94 \mathrm{~min}$.

Parameters of Michaelis-Menten kinetics were calculated with non-linear regression for ABTS and 2,6-DMP as substrates. Values of Michaelis constant, turnover number, and catalytic efficiency (specificity constant) for each substrate are summarized in Table 2. The Michaelis constant $\left(K_{\mathrm{M}}\right)$ for ABTS is twofold higher than for 2,6-DMP, which indicates that the concentration of ABTS has to be higher to reach maximum velocity. Both substrates have similar turnover numbers $\left(k_{\text {cat }}\right)$, but 2,6-DMP has a higher specificity constant $\left(k_{\text {cat }} K_{\mathrm{M}}^{-1}\right)$ indicating that this substrate is preferably used by Tvlcc 5 .

Chloride and sulfate salts of a range of metals were tested for their ability to influence Tvlcc 5 activity. The results summarized in Table 3 show that in most cases activity decreased in the presence of chloride salts, whereas in the presence of sulfate salts activity remained stationary or slightly increased. This indicates that most metal ions have no effect on Tvlcc5 activity, with $\mathrm{Fe}$ being the only exception. Both $\mathrm{FeCl}_{3}$ and $\mathrm{FeSO}_{4}$ caused a strong reduction in enzyme activity indicating an overall negative influence of iron ions.

\section{Fed-batch cultivation}

A lab-scale cultivation of $A$. adeninivorans G1212/ YRC102-TEF1-TVLCC5-6H was required to obtain enough enzyme to study the Tvlcc5 degradation of pharmaceuticals. After the initial glucose was utilized to a residual concentration of $4.44 \pm 0.16 \mathrm{~g} \mathrm{~L}^{-1}$, automated and growth-controlled feeding was initialized. The cultivation was concluded after $160 \mathrm{~h}$ with a final dry cell weight of $96.52 \pm 3.51 \mathrm{~g} \mathrm{~L}^{-1}$ and an extracellular laccase activity of $4986.3 \mathrm{U} \mathrm{L}^{-1}$ resulting in yields of $51.66 \mathrm{U} \mathrm{g}_{\mathrm{DCW}}^{-1}, 37.2 \mathrm{U} \mathrm{g}_{\mathrm{glc}}^{-1}$, and $0.72 \mathrm{~g}_{\mathrm{DCW}} \mathrm{g}_{\mathrm{glc}}^{-1}$. The time course of dry cell weight, glucose concentration and Tvlcc5 activity are shown in Fig. 6.

\section{Degradation of carbamazepine, diclofenac, and sulfamethoxazole}

Investigations on Tvlcc5 laccase mediated degradation of three common pharmaceutical pollutants of wastewater (carbamazepine, diclofenac, and sulfamethoxazole) (Sacher et al. 2008; European Environment Agency 2010) showed significant effects in case of diclofenac (46.8\% breakdown) and sulfamethoxazole (51.1\% breakdown), whereas carbamazepine remained 

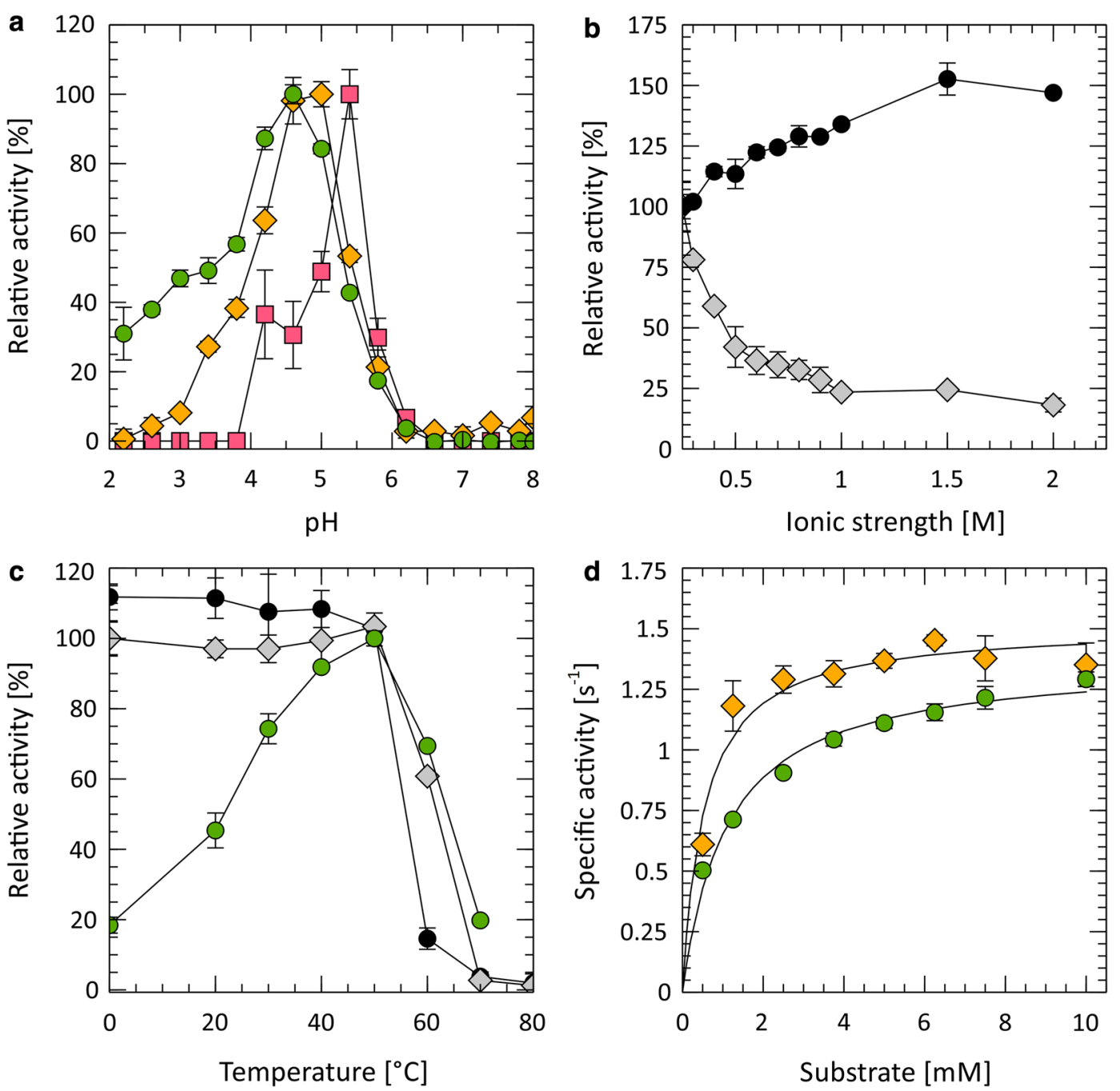

Fig. 5 a Effect of pH on the activity of purified Tvlcc5 with ABTS (green circle), 2,6-DMP (yellow diamond), and SGZ (pink square) as substrate. Activity was calculated in relation to the maximum value for each substrate. $\mathbf{b}$ Influence of ionic strength on the activity of purified Tvlcc5. Ionic strength was adjusted using $\mathrm{NaNO}_{3}$ (black circle) or $\mathrm{NaCl}$ (grey diamond). The activity in pure buffer without addition of any salt was set to $100 \%$. c Effect of temperature (green circle) on the activity of Tvlcc5 and residual activity after incubation at various temperatures for 10 (grey diamond) and 60 min (black circle). $\mathbf{d}$ Influence of the concentration of ABTS (green circle) and 2,6-DMP (yellow diamond) on the specific activity of purified Tvlcc5

Table 2 Michaelis-Menten kinetic constants of purified Tvlcc5

\begin{tabular}{lcc}
\hline & \multicolumn{1}{c}{ ABTS } & 2,6-DMP \\
\hline$K_{\mathrm{M}}(\mathrm{mM})$ & $1.1 \pm 0.1$ & $0.5 \pm 0.1$ \\
$k_{\mathrm{cat}}\left(\mathrm{s}^{-1}\right)$ & $1.4 \pm 0.0$ & $1.5 \pm 0.0$ \\
$k_{\text {cat }} K_{\mathrm{M}}^{-1}\left(\mathrm{mM}^{-1} \mathrm{~s}^{-1}\right)$ & $1243.5 \pm 291.4$ & $2808.3 \pm 473.6$
\end{tabular}

Enzymatic activities were measured in $50 \mathrm{mM}$ citrate-phosphate buffer $\mathrm{pH} 5.0$ and $25^{\circ} \mathrm{C}$

virtually unaffected (Fig. 7a-c). Addition of the laccase mediator ABTS significantly increased the efficiency of Tvlcc5. Under these conditions, diclofenac and sulfamethoxazole were fully degraded within $1 \mathrm{~h}$ of incubation. Carbamazepine, on the other hand, remained unaffected (Fig. 7d).

\section{Discussion}

Of the four laccase genes isolated from the fungi $T$. versicolor and $P$. cinnabarinus, only TVLCC5 was successfully expressed in the host yeast $A$. adeninivorans. Although successful gene insertion (Additional file 1: Fig. S1) as well as transcription were confirmed for all laccase genes (Additional file 1: Fig. S3), no other than $T V L C C 5$ leads to detectable protein neither in supernatant nor within the cells. Even while using the same promoter-terminator combination, the strains showed different transcription patterns. TVLAC and PCLAC 
Table 3 Tvlcc5 activity in the presence of metal salts (1 mM)

\begin{tabular}{lllr}
\hline Addition of: & Activity [\%] & Addition of: & Activity [\%] \\
\hline $\mathrm{CaCl}_{2}$ & $51.9 \pm 0.8$ & $\mathrm{CaSO}_{4}$ & $113.9 \pm 7.3$ \\
$\mathrm{CuCl}_{2}$ & $48.3 \pm 2.3$ & $\mathrm{CuSO}_{4}$ & $111.1 \pm 3.1$ \\
$\mathrm{FeCl}_{3}$ & $22.1 \pm 11.8$ & $\mathrm{FeSO}_{4}$ & $0.0 \pm 4.9$ \\
$\mathrm{MgCl}_{2}$ & $49.0 \pm 6.7$ & $\mathrm{MgSO}_{4}$ & $106.0 \pm 0.9$ \\
$\mathrm{MnCl}_{2}$ & $30.5 \pm 3.1$ & $\mathrm{MnSO}_{4}$ & $108.9 \pm 1.6$ \\
$\mathrm{NiCl}_{2}$ & $39.0 \pm 5.8$ & $\mathrm{NiSO}_{4}$ & $99.3 \pm 3.0$ \\
$\mathrm{ZnCl}_{2}$ & $38.5 \pm 2.7$ & $\mathrm{ZnSO}_{4}$ & $104.9 \pm 0.7$ \\
$\mathrm{AlCl}_{3}$ & $32.2 \pm 1.7$ & $\mathrm{EDTA}$ & $116.6 \pm 2.3$ \\
$\mathrm{CoCl}_{2}$ & $44.0 \pm 1.3$ & $(-)$ & $100.0 \pm 2.3$ \\
$\mathrm{KCl}$ & $65.5 \pm 4.1$ & & \\
\hline
\end{tabular}

were already detectable after $2 \mathrm{~h}$ of cultivation, whereas signals for mRNA of TVLCC5 and TVLCC2 were first found in cDNA from samples taken after $24 \mathrm{~h}$. Furthermore, degradation of mRNA from TVLAC seems to occur at a high rate, since no signal was detected anymore after $2 \mathrm{~h}$ of cultivation. This leads to the assumption that either the transcripts for TVLCC2, TVLAC, and PCLAC are not translated at all, which could be caused by rapid degradation and issues with secondary structure, or they are translated but the freshly formed protein is immediately degraded due to putative protease recognition sites. By means of multiple sequence alignment (Additional file 1: Fig. S5) we identified six domains with amino acid sequence differences that may be related to this problem. The identified sequences show a high degree of similarity or are even identical between Tvlac, Tvlcc2, and Pclac. The amino acid sequence of Tvlcc5, on the other hand, differs in those positions, e.g., 49-51 LAG instead of VVN (47-49 Tvlac and Tvlcc2; 48-50 Pclac), 253-255 HEA instead of SQP/TQP (248-250 Tvlac and Tvlcc2; 249-251 Pclac), 294-296 DTT instead of GFA (289-291 Tvlac and Tvlcc2; 290-292 Pclac), 308-310 TAE instead of GAP (303-305 Tvlac and Tvlcc2; 304-306 Pclac), 346348 PAA instead of MPV (341-343 Tvlac and Tvlcc2; 342-344 Pclac) or 433-435 TFS (428-430 Tvlac and Tvlcc2; 429-431 Pclac) instead of AFA (Additional file 1: Fig. S5). Furthermore, the domain IITTD in position 411-415 of Tvlcc5, which is absent from Tvlcc2, Tvlac and Pclac, could be involved in post translational modifications. The absence of this sequence could be another cause for the early degradation of the three proteins. Post-translational modifications are often species specific and failures can lead to incorrect folding by chaperones, different pattern of glycosylation, phosphorylation, or disulfide bonds formation during recombinant protein production (Tokmakov et al. 2012; Kim et al. 2015). It is conceivable that A. adeninivorans is unable to process those modifications for different proteins with the same efficiency, leading to the production of non-functional proteins prone to degradation. Issues with codon usage bias, on the other hand, are more unlikely since an analysis of the codon-usage showed that all four laccase genes show some rare codons, but none of them would be excluded from being translated by $A$. adeninivorans. The distribution of Tvlcc5 between intra- and extracellular space as well as the signals of protein degradation products indicate an ineffective secretion of this enzyme by the host. Since we used the native signal sequence in this study, a closer investigation into yeast signal peptides may be worthwhile. The use of both native laccase and
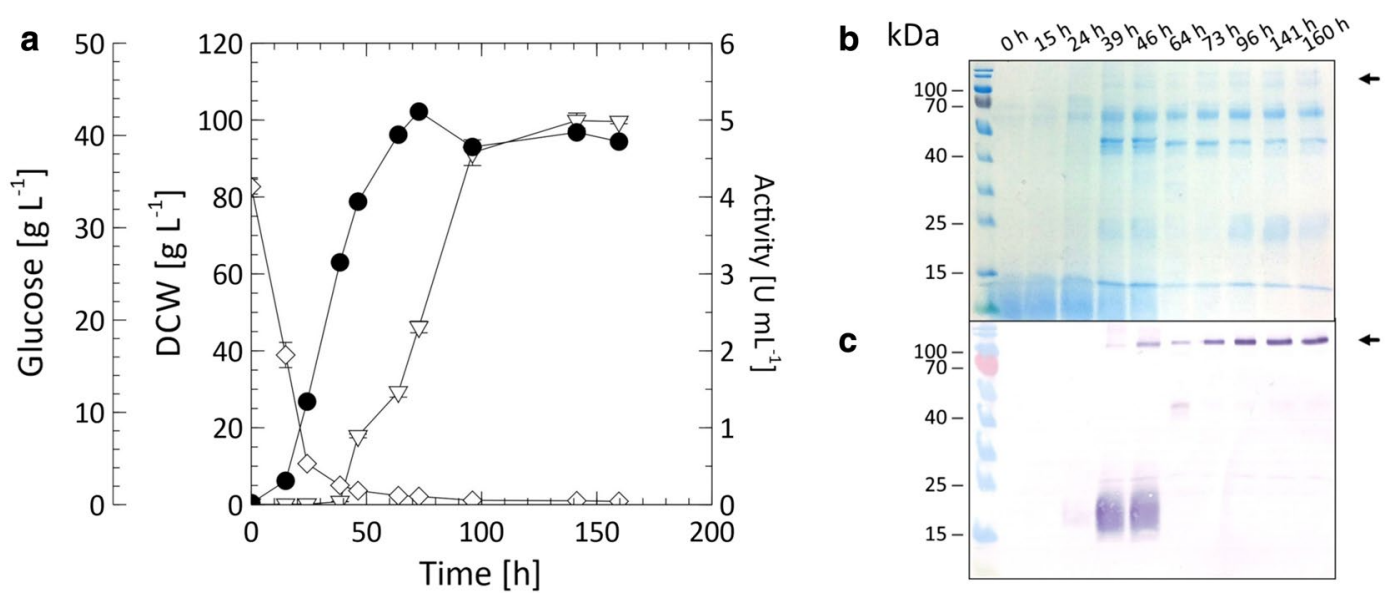

Fig. 6 a Time course of DCW (black circle), glucose concentration (white diamond), and laccase activity (white up-pointing triangle) during a representative fed-batch cultivation of $A$. adeninivorans G1212/YRC102-TEF1-TVLCC5-6H. Coomassie-stained SDS-PAGE (b) and western-blot analysis with anti-6xHis antibody c show the accumulation of recombinant Tvlcc5 in the supernatant of samples taken at each time point 

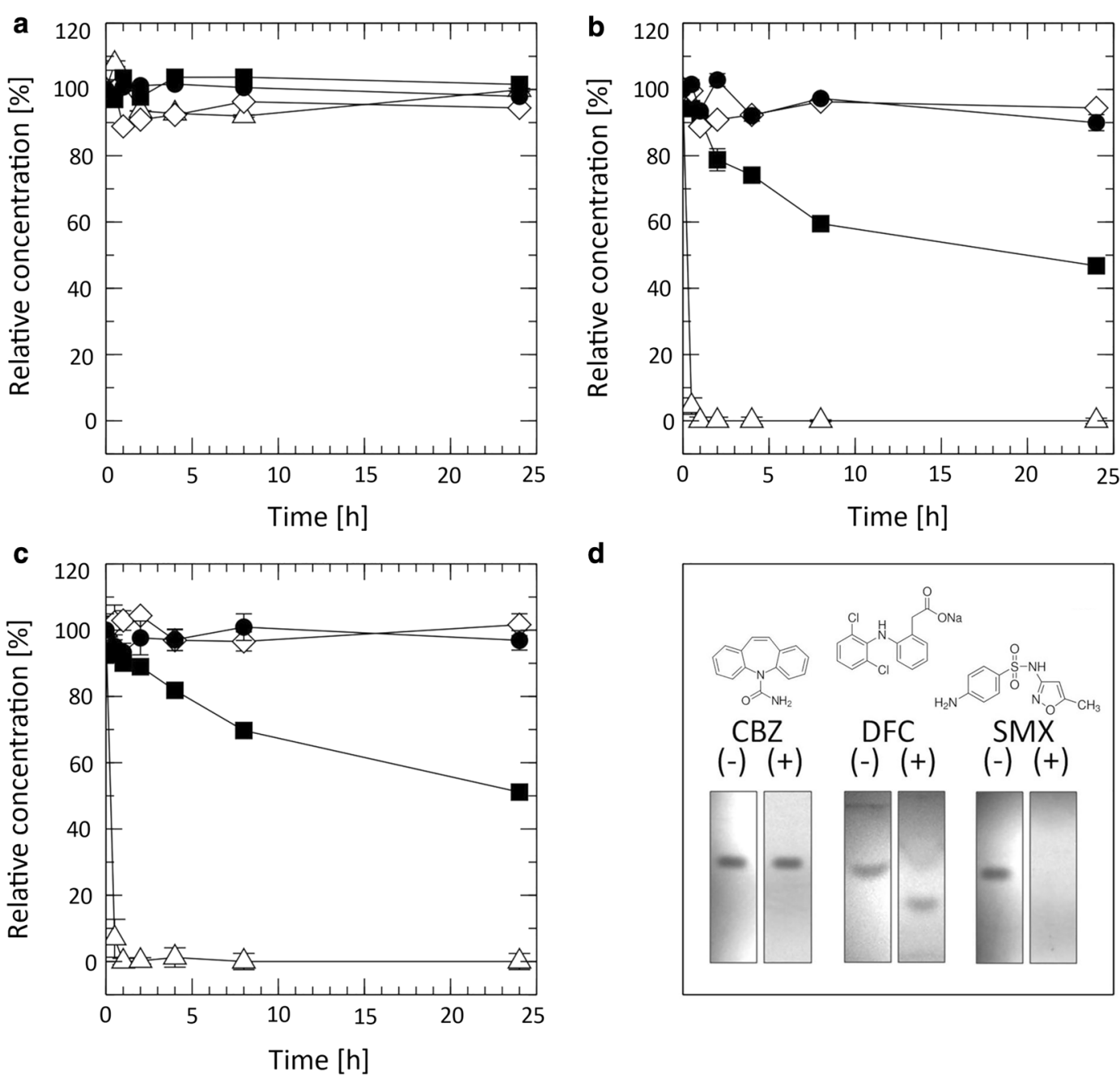

d

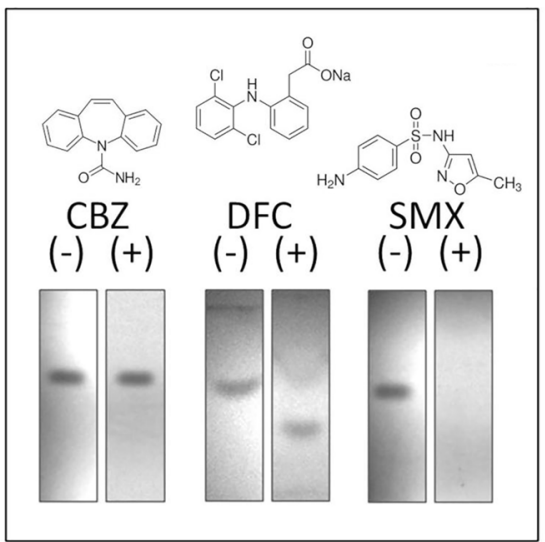

Fig. 7 Degradation courses of carbamazepine (a), diclofenac (b), and sulfamethoxazole (c). Reaction mixtures containing pharmaceutical and Tvlcc5 in the absence (black square) or presence of $1 \mathrm{mM} \mathrm{ABTS} \mathrm{(white} \mathrm{up-pointing} \mathrm{triangle)} \mathrm{were} \mathrm{compared} \mathrm{with} \mathrm{reaction} \mathrm{mixtures} \mathrm{containing}$ pharmaceuticals only in the absence (black circle) or presence of $1 \mathrm{mM}$ ABTS (white diamond). $\mathbf{d}$ Thin layer chromatography plates showing influence of ABTS (+) on degradation of pharmaceuticals

host-originated signal peptides has been reported previously (Jönsson et al. 1997; Brown et al. 2002; Piscitelli et al. 2005). Results differ for each enzyme and host organism, leading to the conclusion, that choice of the most efficient signal peptide is not easy to predict and must be assayed for each expression system separately.

Determination of the molecular mass of native Tvlcc5 yielded a value of $100 \mathrm{kDa}$ which is significantly larger than the $53.6 \mathrm{kDa}$ predicted from the amino acid sequence. Screening of the PROSITE database (de Castro et al. 2006) for functional sites, showed that $T$. versicolor lcc5 has 13 potential $N$-glycosylation sites. Removal of $\mathrm{N}$-glycans by treatment with PNGase F led to a marked decrease in molecular mass to approx. $70 \mathrm{kDa}$ (Fig. 4). Although this is still higher than the predicted value, the remaining difference could be due to the presence of additional $O$-glycans. Hyperglycosylation by yeasts is a well-known phenomenon and would be the natural explanation for the substantial differences in molecular mass observed (Bulter et al. 2003; Piscitelli et al. 2010; Bischoff et al. 2017). The laccases produced by fungi are de facto glycoproteins that usually have a carbohydrate content of 10-20\% (Thurston 1994; Morozova et al. 2007).

The optimal $\mathrm{pH}$ conditions for Tvlcc5 were within the range 4.5-5.5 for all tested substrates (ABTS, 2,6-DMP, and SGZ). This apparently contradicts many previous reports, showing a variation in $\mathrm{pH}$ optimum depending on which substrate is used (Nitheranont et al. 2011; $\mathrm{Gu}$ et al. 2014; Kalyani et al. 2015). We found the ionic 
strength of the buffer to be a key factor for this discrepancy. Without adjusting the ionic strength, the $\mathrm{pH}$ optimum differs for each substrate ( $\mathrm{pH} 2.6$ for ABTS, $\mathrm{pH} 3.8$ for 2,6-DMP, and $\mathrm{pH} 4.6$ for SGZ). Whereas $\mathrm{SO}_{4}{ }^{2-}$ salts had no or a slightly benign effect on Tvlcc 5 activity, similar concentration of chloride ions was detrimental for Tvlcc 5 activity decreasing enzyme activity by $50 \%$ or more (Table 3). Laccase inhibition by $\mathrm{Cl}^{-}$and other halides had been already observed by Koudelka and Ettinger (1988), Xu (1996) and Garzillo et al. (1998). However, in case of iron salts, both chloride and sulfate compounds inhibited enzyme activity almost completely indicating that Fe ions substantially influence Tvlcc 5 activity as well (Table 3).

Additional evidence for negative influence of $\mathrm{Cl}^{-}$on laccase activity is shown in Fig. 5b. By increasing the ionic strength of the buffer, concentration of $\mathrm{Cl}^{-}$is also increasing, leading to inhibition of laccase activity $(18.2 \pm 2.9 \%$ of the initial value after increase of ionic strength to $2 \mathrm{M}$ ).

Preceding large-scale production of Tvlcc5 optimization procedures were investigated. Different cultivation media were implemented. Cultivation in YPD medium yielded the highest enzyme accumulation (Fig. 2). However, in future during the cultivation in YPD the $\mathrm{pH}$ would have to be regulated to prevent enzyme inactivation. Medium supplementation with different amounts of $\mathrm{CuSO}_{4}$ showed that addition of $\mathrm{Cu}^{2+}$ ions is essential for enzyme activity. Supplementation with $0.5 \mathrm{mM} \mathrm{CuSO}_{4}$ was found to be optimal (Fig. 2).

In case of temperature, both cell growth and laccase activity reached optimal levels at $20{ }^{\circ} \mathrm{C}\left(9.4 \mathrm{~g} \mathrm{~L}^{-1}\right.$, $0.35 \mathrm{U} \mathrm{mL}^{-1}$, respectively) (Fig. 3). Laccase accumulation was only slightly lower at $30{ }^{\circ} \mathrm{C}\left(0.33 \mathrm{U} \mathrm{mL}^{-1}\right)$, but showed a marked decline under higher temperatures. This may be due to the temperature-dependent dimorphism of $A$. adeninivorans, which at $42{ }^{\circ} \mathrm{C}$ transitions from budding cells into mycelia (Wartmann et al. 1995).

A fed-batch cultivation of A. adeninivorans G1212/ YRC102-TEF1-TVLCC5-6H achieved a laccase production of $4986.3 \mathrm{U} \mathrm{L}^{-1}$ (Fig. 6), which is more than threefold higher than obtained by Brown et al. (2002) using $P$. pastoris for the production of the same isozyme from $T$. versicolor. Phenols are the typical natural substrates for laccases. However, under certain conditions laccases may also oxidize non-phenolic substrates. The oxidation reaction can be enhanced by addition of appropriate mediators (Bourbonnais and Paice 1990; Baiocco et al. 2003; Cañas and Camarero 2010). The pharmaceuticals tested in this study are non-phenolic substrates. We found the redox mediator ABTS to play a key role in accelerating the degradation of diclofenac and sulfamethoxazole, though it had no influence on the degradation of carbamazepine. To address this problem, an alternative laccase-mediator system may be necessary (Baiocco et al. 2003). Considering environmental and economic aspects natural mediators should be preferred. Future work will concentrate on generating a stable yeast strain, optimized for both laccase and cytochrome $\mathrm{P} 450$ production, which can be applied as a whole-cell catalyst for the deactivation of active pharmaceutical compounds in wastewater treatment plants. An important issue to solve in the future is the distribution of laccase. Rather than it being secreted into the environment it would be optimal to locally concentrate this enzyme by attachment to the cell surface. Another option would be the co-immobilization of enzyme with yeast cells.

\section{Additional file}

Additional file 1. Table S1. Sequences of primers for gene amplification and reverse transcription PCR. Fig. S1. PCR on genomic DNA of $A$. adeninivorans $\mathrm{G} 1212$ strains expressing laccase genes using primers for gene amplification. As negative controls the same $P C R$ reactions were performed using genomic DNA of A. adeninivorans G1212(-) as template. Thermo Scientific O'GeneRuler 1 kb Plus served as DNA ladder. Fig. S2.

(I) Intracellular (upper row) and extracellular (lower row) laccase activity of (a) A. adeninivorans $\mathrm{G} 1212$ (negative control) and strains expressing (b) TVLCC5, (c)TVLCC2, (d) TVLAC, (e) PCLAC genes. (II) Western-blot and Coomassie-stained SDS-PAGE analysis of intracellular $(1,3)$ and extracellular $(2,4)$ fractions isolated after $48(1,2)$ and $120 \mathrm{~h}(3,4)$ of cultivation. (III) Distribution of Tvlcc5 protein between intracellular (dark grey) and extracellular (light grey) fraction during $120 \mathrm{~h}$ cultivation of $A$. adeninivorans G1212/YRC102-TEF1-TVLCC5-6H. Fig. S3. (a) RT-PCR on samples taken from $A$. adeninivorans G1212/YRC102-TVLCC5-6H, A. adeninivorans G1212/YRC102-TVLCC2-6H, A. adeninivorans G1212/YRC102-TVLAC-6H, A. adeninivorans G1212/YRC102-PCLAC-6H, and A. adeninivorans G1212/ YRC102 after $24 \mathrm{~h}$ of cultivation for amplification of fragments of TVLCC5 (1), TVLAC (2), PCLAC (3), AAHEXK (H), and AATFIID (T) using primers shown in Table S1. (b) RT-PCR on samples taken from A. adeninivorans G1212/ YRC102-TVLAC-6H after the indicated cultivation time for amplification of a fragment of TVLAC. (c) RT-PCR on samples taken from the same cultivations after $2 \mathrm{~h}$ for amplification of fragments of TVLCC5 (1), TVLAC (2), PCLAC (3), AAHEXK (H), and AATFIID (T) using primers shown in Table S1. Fig. S4. Effect of $\mathrm{pH}$ on the activity of purified Tvlcc5 with ABTS (green circle), 2,6-DMP (yellow triangle), and SGZ (pink square) as substrate in presence of buffers without equalized ionic strength. Activity was calculated in relation to the maximum value for each substrate. Fig. S5. Alignment of the protein sequences derived from TVLCC5, TVLAC, TVLCC2, and PCLAC genes in box shade format. Black box shows identical amino acids. Grey box implies amino acids with similar residues. White text indicates amino acids without similarities.

\section{Abbreviations}

ABTS: 2,2'-azino-bis(3-ethylbenzothiazoline-6-sulphonic acid); YRC: yeast rDNA integrative expression cassette; YIC: yeast integrative expression cassette; 2,6DMP: 2,6-dimethoxyphenol; SGZ: syringaldazine; DCW: dry cell weight.

\section{Acknowledgements}

We would like to thank Undine Klän for her technical assistance. 


\section{Authors' contributions}

$\mathrm{KL}$ contributed in conception, research design, carried out the experiments, analyzed the results and was a major contributor in writing the manuscript. FB contributed in conception, research design, data interpretation and manuscript draft. FM participated in research design, data interpretation and manuscript draft. RB participated in the design of the study and data interpretation. TR contributed in conception of the manuscript, provided writing assistance. GK conceived of and coordinated the study, contributed in the preparation of the manuscript. All authors read and approved the final manuscript.

\section{Funding}

This study was funded by Grant from the German Federal Ministry for Economic Affairs and Energy (BMWi-Grant No. KF2131628SA4).

\section{Availability of data and materials}

The data sets supporting the conclusions of this article are included within the article. Further data (named data not shown in the manuscript) are available from the corresponding author on reasonable request.

\section{Ethics approval and consent to participate}

This article does not contain any studies with human participants or animals performed by any of the authors.

\section{Consent for publication}

Not applicable.

\section{Competing interests}

The authors declare that they have no competing interests.

\section{Author details}

${ }^{1}$ Leibniz Institute of Plant Genetics and Crop Plant Research (IPK), Corrensstr. 3, 06466 Gatersleben, Germany. ${ }^{2}$ Jäckering Mühlen- und Nährmittelwerke GmbH, Vorsterhauser Weg 46, 59007 Hamm, Germany. ${ }^{3}$ Institute of Microbiology, University of Greifswald, Jahnstr. 15, 17487 Greifswald, Germany.

\section{Received: 29 June 2019 Accepted: 4 July 2019}

Published online: 11 July 2019

\section{References}

Andreozzi R, Raffaele M, Nicklas P (2003) Pharmaceuticals in STP effluents and their solar photodegradation in aquatic environment. Chemosphere 50:1319-1330. https://doi.org/10.1016/S0045-6535(02)00769-5

Baiocco P, Barreca AM, Fabbrini M, Galli C, Gentili P (2003) Promoting laccase activity towards non-phenolic substrates: a mechanistic investigation with some laccase-mediator systems. Org Biomol Chem 1:191-197. https ://doi.org/10.1039/B208951C

Benson DA (2004) GenBank. Nucleic Acids Res 33:D34-D38. https://doi. org/10.1093/nar/gki063

BIO Intelligence Service (2013) Study on the environmental risks of medicinal products. Final report prepared for Executive Agency for Health and Consumers

Bischoff F, Chamas A, Litwińska K, Matthes F, Böer E, Kunze G (2017) Applications of Blastobotrys (Arxula) adeninivorans in biotechnology. In: Satyanarayana T, Kunze G (eds) Yeast diversity in human welfare. Springer Singapore, Singapore, pp 455-479

Bound JP, Voulvoulis N (2005) Household disposal of pharmaceuticals as a pathway for aquatic contamination in the United Kingdom. Environ Health Perspect 113:1705-1711. https://doi.org/10.1289/ehp.8315

Bourbonnais R, Paice MG (1990) Oxidation of non-phenolic substrates. An expanded role for laccase in lignin biodegradation. FEBS Lett 267:99-102. https://doi.org/10.1016/0014-5793(90)80298-w

Brown MA, Zhao Z, Mauk AG (2002) Expression and characterization of a recombinant multi-copper oxidase: laccase IV from Trametes versicolor. Inorg Chim Acta 331:232-238. https://doi.org/10.1016/s0020 -1693(01)00814-3

Bulter T, Alcalde M, Sieber V, Meinhold P, Schlachtbauer C, Arnold FH (2003) Functional expression of a fungal laccase in Saccharomyces cerevisiae by directed evolution. Appl Environ Microbiol 69:987-995. https://doi. org/10.1128/AEM.69.2.987
Cañas Al, Camarero S (2010) Laccases and their natural mediators: biotechnological tools for sustainable eco-friendly processes. Biotechnol Adv 28:694-705. https://doi.org/10.1016/j.biotechadv.2010.05.002

Carballa M, Omil F, Lema JM, Llompart M, Garcia-Jares C, Rodríguez I, Gómez $M$, Ternes T (2004) Behavior of pharmaceuticals, cosmetics and hormones in a sewage treatment plant. Water Res 38:2918-2926. https://doi. org/10.1016/j.watres.2004.03.029

de Castro E, Sigrist CJA, Gattiker A, Bulliard V, Langendijk-Genevaux PS, Gasteiger E, Bairoch A, Hulo N (2006) ScanProsite: detection of PROSITE signature matches and ProRule-associated functional and structural residues in proteins. Nucleic Acids Res 34:W362-W365. https://doi. org/10.1093/nar/gkl124

European Environment Agency (2010) Pharmaceuticals in the environmentresults of an EEA workshop. EEA technical report No 1/2010. European Environment Agency, Copenhagen

Fent K, Weston A, Caminada D (2006) Ecotoxicology of human pharmaceuticals. Aquat Toxicol 76:122-159. https://doi.org/10.1016/j.aquat ox.2005.09.009

Furge LL, Guengerich FP (2006) Cytochrome P450 enzymes in drug metabolism and chemical toxicology: an introduction. Biochem Mol Biol Educ 34:66-74. https://doi.org/10.1002/bmb.2006.49403402066

Garzillo AMV, Colao MC, Caruso C, Caporale C, Celletti D, Buonocore V (1998) Laccase from the white-rot fungus Trametes trogii. Appl Microbiol Biotechnol 49:545-551. https://doi.org/10.1007/s002530051211

Gianfreda L, Xu F, Bollag J-M (1999) Laccases: a useful group of oxidoreductive enzymes. Bioremediat J 3:1-26. https://doi.org/10.1080/1088986999 1219163

Giardina P, Faraco V, Pezzella C, Piscitelli A, Vanhulle S, Sannia G (2010) Laccases: a never-ending story. Cell Mol Life Sci 67:369-385. https://doi. org/10.1007/s00018-009-0169-1

Gu C, Zheng F, Long L, Wang J, Ding S (2014) Engineering the expression and characterization of two novel laccase isoenzymes from Coprinus comatus in Pichia pastoris by fusing an additional ten amino acids tag at N-terminus. PLoS ONE 9:e93912. https://doi.org/10.1371/journal.pone.0093912

Herter S, Mikolasch A, Michalik D, Hammer E, Schauer F, Bornscheuer U, Schmidt M (2011) C-N coupling of 3-methylcatechol with primary amines using native and recombinant laccases from Trametes versicolor and Pycnoporus cinnabarinus. Tetrahedron 67:9311-9321. https://doi. org/10.1016/j.tet.2011.09.123

Huschek G, Hansen PD, Maurer HH, Krengel D, Kayser A (2004) Environmental risk assessment of medicinal products for human use according to European Commission recommendations. Environ Toxicol 19:226-240. https ://doi.org/10.1002/tox.20015

Jönsson LJ, Saloheimo M, Penttilä M (1997) Laccase from the white-rot fungus Trametes versicolor: cDNA cloning of /cc1 and expression in Pichia pastoris. Curr Genet 32:425-430. https://doi.org/10.1007/s002940050298

Joss A, Zabczynski S, Göbel A, Hoffmann B, Löffler D, McArdell CS, Ternes TA, Thomsen A, Siegrist H (2006) Biological degradation of pharmaceuticals in municipal wastewater treatment: proposing a classification scheme. Water Res 40:1686-1696. https://doi.org/10.1016/j.watres.2006.02.014

Kalyani D, Tiwari MK, Li J, Kim SC, Kalia VC, Kang YC, Lee J-K (2015) A highly efficient recombinant laccase from the yeast Yarrowia lipolytica and its application in the hydrolysis of biomass. PLoS ONE 10:e0120156. https:// doi.org/10.1371/journal.pone.0120156

Keil F (ed) (2008) Pharmaceuticals for human use: options of action for reducing the contamination of water bodies - a practical guide. Institute for Social-Ecological Research (ISOE) GmbH Research Project start

Kiiskinen LL, Rättö M, Kruus K (2004) Screening for novel laccase-producing microbes. J Appl Microbiol 97:640-646. https://doi.org/10.111 1/j.1365-2672.2004.02348.x

Kim H, Yoo SJ, Kang HA (2015) Yeast synthetic biology for the production of recombinant therapeutic proteins. FEMS Yeast Res 15:1-16. https://doi. org/10.1111/1567-1364.12195

Koudelka GB, Ettinger MJ (1988) Fluoride effects on the activity of Rhus laccase and the catalytic mechanism under steady-state conditions. J Biol Chem 263:3698-3705

Kunze G, Kunze I (1994) Characterization of Arxula adeninivorans strains from different habitats. Antonie Van Leeuwenhoek 65:29-34. https://doi. org/10.1007/BF00878276

Laemmli UK (1970) Cleavage of structural proteins during assembly of the head of bacteriophage T4. Nature 227:680-685 
Morozova OV, Shumakovich GP, Gorbacheva MA, Shleev SV, Yaropolov Al (2007) "Blue" laccases. Biochemistry 72:1136-1150. https://doi. org/10.1134/S0006297907100112

Nitheranont T, Watanabe A, Asada Y (2011) Extracellular laccase produced by an edible basidiomycetous mushroom, Grifola frondosa: purification and characterization. Biosci Biotechnol Biochem 75:538-543. https://doi. org/10.1271/bbb.100790

Okuda T, Kobayashi Y, Nagao R, Yamashita N, Tanaka H, Tanaka S, Fujii S, Konishi C, Houwa I (2008) Removal efficiency of 66 pharmaceuticals during wastewater treatment process in Japan. Water Sci Technol 57:65. https:// doi.org/10.2166/wst.2008.822

Ong E, Pollock WB, Smith M (1997) Cloning and sequence analysis of two laccase complementary DNAs from the ligninolytic basidiomycete Trametes versicolor. Gene 196:113-119. https://doi.org/10.1016/S0378 $-1119(97) 00215-1$

Otterbein L, Record E, Longhi S, Asther M, Moukha S (2000) Molecular cloning of the cDNA encoding laccase from Pycnoporus cinnabarinus 1-937 and expression in Pichia pastoris. Eur J Biochem 267:1619-1625. https://doi. org/10.1046/j.1432-1327.2000.01166.x

Peña A, Pardo JP, Ramírez J (1987) Early metabolic effects and mechanism of ammonium transport in yeast. Arch Biochem Biophys 253:431-438. https ://doi.org/10.1016/0003-9861(87)90196-2

Piscitelli A, Giardina P, Mazzoni C, Sannia G (2005) Recombinant expression of Pleurotus ostreatus laccases in Kluyveromyces lactis and Saccharomyces cerevisiae. Appl Microbiol Biotechnol 69:428-439. https://doi.org/10.1007/ s00253-005-0004-z

Piscitelli A, Pezzella C, Giardina P, Faraco V, Sannia G (2010) Heterologous laccase production and its role in industrial applications. Bioeng Bugs 1:254-264. https://doi.org/10.4161/bbug.1.4.11438

Rose M, Winston F, Hieter P (1990) Methods in yeast genetics - a laboratory course manual. Cold Spring Harbor, New York

Sacher F, Ehmann M, Gabriel S, Graf C, Brauch H-J (2008) Pharmaceutical residues in the river Rhine-results of a one-decade monitoring programme. J Environ Monit 10:664. https://doi.org/10.1039/b800701b

Seehusen DA, Edwards J (2006) Patient practices and beliefs concerning disposal of medications. J Am Board Fam Med 19:542-547. https://doi. org/10.3122/jabfm.19.6.542

Soden DM, O'Callaghan J, Dobson ADW (2002) Molecular cloning of a laccase isozyme gene from Pleurotus sajor-caju and expression in the heterologous Pichia pastoris host. Microbiology 148:4003-4014. https:// doi.org/10.1099/00221287-148-12-4003

Steinborn G, Gellissen G, Kunze G (2007) A novel vector element providing multicopy vector integration in Arxula adeninivorans. FEMS Yeast Res 7:1197-1205. https://doi.org/10.1111/j.1567-1364.2007.00280.x

Tanaka A, Ohnishi N, Fukui S (1967) Studies on the formation of vitamins and their function in hydrocarbon fermentation. Production of vitamin B6 by Candida albicans in hydrocarbon medium. J Ferment Technol 45:617-623

Thurston CF (1994) The structure and function of fungal laccases. Microbiology 140:19-26. https://doi.org/10.1099/13500872-140-1-19

Tokmakov AA, Kurotani A, Takagi T, Toyama M, Shirouzu M, Fukami Y, Yokoyama S (2012) Multiple post-translational modifications affect heterologous protein synthesis. J Biol Chem 287:27106-27116. https://doi.org/10.1074/ jbc.M112.366351

Touraud E, Roig B (2008) KNAPPE Project. Knowledge and Need Assessment on Pharmaceutical Products in Environmental Waters. Final report. European DG Research (Sixth Framework Programme)

Vylkova S, Carman AJ, Danhof HA, Collette JR, Zhou H, Lorenz MC (2011) The fungal pathogen Candida albicans autoinduces hyphal morphogenesis by raising extracellular pH. MBio 2:1-12. https://doi.org/10.1128/ mBio.00055-11

Wartmann T, Krüger A, Adler K, Minh Duc B, Kunze I, Kunze G (1995) Temperature-dependent dimorphism of the yeast Arxula adeninivorans Ls3. Antonie Van Leeuwenhoek 68:215-223. https://doi.org/10.1007/ bf00871818

Wrighton SA, Stevens JC (1992) The human hepatic cytochromes P450 involved in drug metabolism. Crit Rev Toxicol 22:1-21. https://doi. org/10.3109/10408449209145319

Xu F (1996) Oxidation of phenols, anilines, and benzenethiols by fungal laccases: correlation between activity and redox potentials as well as halide inhibition. Biochemistry 35:7608-7614. https://doi.org/10.1021/bi952 971a

\section{Publisher's Note}

Springer Nature remains neutral with regard to jurisdictional claims in published maps and institutional affiliations.

\section{Submit your manuscript to a SpringerOpen ${ }^{\circ}$ journal and benefit from:}

- Convenient online submission

- Rigorous peer review

- Open access: articles freely available online

- High visibility within the field

Retaining the copyright to your article

Submit your next manuscript at springeropen.com 